\title{
Yves Reboul, «Beams» et le «nous» verlainien, «Littératures» n 57
}

Ida Merello

\section{(2) OpenEdition}

1 Journals

\section{Edizione digitale}

URL: http://journals.openedition.org/studifrancesi/8030

DOI: ERREUR PDO dans/localdata/www-bin/Core/Core/Db/Db.class.php L.34 : SQLSTATE[HY000]

[2006] MySQL server has gone away

ISSN: 2421-5856

\section{Editore}

Rosenberg \& Sellier

\section{Edizione cartacea}

Data di pubblicazione: 1 juillet 2009

Paginazione: 430

ISSN: 0039-2944

\section{Notizia bibliografica digitale}

Ida Merello, «Yves Reboul, «Beams» et le «nous» verlainien, «Littératures» n 57», Studi Francesi [Online], 158 (LIII | II) | 2009, online dal 30 novembre 2015, consultato il 07 janvier 2021. URL: http://

journals.openedition.org/studifrancesi/8030 ; DOI: https://doi.org/10.4000/studifrancesi.8030

Questo documento è stato generato automaticamente il 7 janvier 2021.

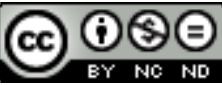

Studi Francesi è distribuita con Licenza Creative Commons Attribuzione - Non commerciale - Non opere derivate 4.0 Internazionale. 


\title{
Yves Reboul, «Beams» et le «nous» verlainien, «Littératures» ${ }^{\circ} 57$
}

\author{
Ida Merello
}

\section{NOTIZIA}

YVES REBOUL, «Beams» et le «nous» verlainien, «Littératures» n5 57, 2007, pp. 251-256.

L'A. prende in esame il lungo componimento in quartine di alessandrini, Mort, che Verlaine pubblicò su «La Revue rouge» di Montmartre poco tempo prima di morire, per mettere in luce il sogno di sovversione violenta che lo anima. La contestualizzazione storica permette di definire con precisione l'atteggiamento politicamente anarchico del poeta; mentre resta da precisare quel pronome personale «nous» che scandisce il componimento e che è presente anche in Beams. L'A. ricorda come il «nous» sia molto presente anche nelle Fêtes galantes e in maniera non univoca, per quanto stia spesso a rappresentare la giovane intelligentsia francese della fine del Secondo Impero. È questo il «nous» che l'A. identifica in Mort e in Beams, ossia verosimilmente quello del gruppo di discepoli che seguono la Buona novella della poesia di Rimbaud. 